\title{
South Africa's Economic and Fiscal Quagmire: A Political and Insurrectionary Dilemma as Rating Agencies Downgrade the South African Economy and Minister of Finance Fired by the President Without any Tangible Reasons
}

\author{
Anis Mahomed Karodia ${ }^{1}$, Sayed Rehman ${ }^{1} \&$ Paresh Soni $^{2}$ \\ ${ }^{1}$ Regent Business School, Durban, Republic of South Africa \\ ${ }^{2}$ Management College of Southern Africa (Mancosa), Durban, Republic of South Africa \\ Correspondence: Anis Mahomed Karodia, Regent Business School, Durban, Republic of South Africa. E-mail: \\ akarodia@ regent.ac.za
}

Received: November 20, 2015

Accepted: January 6, 2016

Online Published: February 25, 2016

doi: 10.5539/ibr.v9n3p175

URL: http://dx.doi.org/10.5539/ibr.v9n3p175

\begin{abstract}
This narrative attempts to deal with the title of the paper in terms of the South Africa's economic and fiscal quagmire and crisis. In no way is the paper all inclusive because, it cannot capture all of the subtle nuances that encompass this vexing issue, nearly two decades after the dawn and road to democracy, post 1994. The Finance Minister is in a no win situation and has to play the tune of his political masters. The Ministers mid-term review tabled to the nation in October, 2015 shows that he has to walk a very tight rope because of the current account, fiscal deficit and points to the reality that the business outlook is bleak. The reality question is, is it economic power or political power? The downgrade risks that the country faces on the part of rating agencies makes Minister Nene's Job even more trickier and therefore, faces a near impossible balancing act' to appease rating agencies. Can the Minister keep the credit agency wolves from the Treasury door? South Africa is in an economic and fiscal turmoil as it dips into savings to pay its monthly bills and therefore, reserve funds are being diverted into bureaucrats' salaries. It is not only the question of the prolonged economic meltdown, but in reality it has to do with the mismanagement of the economy by the ruling government. The very high levels of corruption, cronyism, a mismatch in policy imperatives, the failure to action holistically the National Development Plan (NDP) and, a number of variables that have placed South Africa in this extreme quagmire, exacerbated by increasing unemployment, depressing poverty levels and rising inequality. The only solution is to deal decisively with corruption and to generate rapid growth by means of policy certainty. Against this background the paper will attempt to discuss these and other scenarios that confront South Africa.
\end{abstract}

Keywords: economy, fiscal, quagmire, political, insurrection, mismanagement, governance, budget, national development plan, deficits, downgrade, scenarios, debt, rating agencies

\section{Introduction}

South Africa is its worst enemy as we deal with ineffective politicians, self-serving politicians in the main and as a country we move from one crisis to another in the absence of policy certainty and, a country bedeviled by overt and endemic corruption, strikes and protests, patronage and an absolute lack of decisive leadership. To this end the ordinary citizen is losing hope and confidence in a public service bureaucracy that cannot be held accountable by ineffective and self-serving politicians. The recent violent student protests as concerns higher education in respect of the \#FeesMustFall campaign is also the Finance Minister's nightmare. The issue is do we want to show this picture to the world? "It is a country that is in perpetual paralysis and which is damaging. All of this risks undoing even the smallest of progress that has been achieved in 21 years of democracy and revolution" (Mnyandu, 2015, p. 18). Never in the history of post-apartheid South Africa has the Finance Ministers mid-term budget been / was delayed, but it was for over an hour because higher education students stormed parliament, but the minister and ruling party politicians paid scant reference to this crisis in spite of opposition political parties calling for the postponement of the ministers mid-term budget. The ruling party failed the nation and the minister presented his budget with great indifference to the crisis outside parliament. But even to an uninitiated eye, it is easy to see that South Africa's socio-economic strains are becoming untenable. The 
government according to Mnyandu (2015, p. 18) "needs to articulate why 21 years after the country was to have a fresh start there still remains such entrenched poverty, lawlessness, corruption and a total breakdown in societal mores." Increasingly, this is the picture that the South Africa of today keeps portraying to the outside world, and there seems nothing to alter it. Mnyandu (2015, p. 18) states that "The Economist magazine ran a cover story three years ago entitled 'Sad South Africa: Cry the Beloved Country', raising the ire of the administration as ill-informed, misguided and prejudicial." In reality the article was spot on and we find in 2015 that very little has changed. It portrays a country in perpetual paralysis and the government of South Africa must realize and take cognizance of this fact and, therefore, take note that 1994 is not a distant memory, even to the current generation of students and the youth of the country. South Africa needs to change course, and the time to do that is now.

A fallout from South Africa's intractable problem according to Mnyandu and Khuzwayo (2015, p. 1) is the reality that "there is stunted growth and rising social discontent and not only is faltering growth chipping away at the government's ability to generate more revenue, but it is also constraining the government's ability to fund key programmes." What are the consequences of all of this in terms of world opinion and within the country in general? The following discussion speaks to the various scenarios that emerge.

\section{Research Methodology}

The paper does not use any distinct methodology that is used in classical research. The authors use their own analytical skills through the processes of observation and experience over time and rely heavily on analysis and discussion in the South African media. This in no way dilutes the thrust of the paper. In reality, it is an honest appraisal of the fiscal and economic crisis that confronts the country.

\section{Conclusions and Recommendations}

The conclusions and recommendations are made throughout the narrative and there is no specific paragraph in the article that deals with these issues, except to state that some of the conclusions and recommendations will be made at the end of the paper. In addition, the paper has inserted a narrative on the outcomes of the ratings agencies-Fitch and Standard and Poor. The downgrade of the South African economy was announced on the $28^{\text {th }}$ of November, 2015. In addition it introduces the consequences that now befall South Africa, given the firing of the Minister of Finance by the President on the $9^{\text {th }}$ of December, 2015, without providing any tangible reasons for his actions. This has injured South Africa even more as the Rand fell to its lowest ever exchange rate. It has dampened investor confidence and is now sliding rapidly into 'Junk' status as an economy.

\section{Conclusion}

The paper dealt with pressing fiscal and economic issues that confront South Africa. It alludes to a host of issues that has plagued South Africa, in terms of the mismanagement of the economy. The outcomes of the results of the rating agencies, in the form of Fitch and Standard and Poor were discussed in terms of South Africa's economy being downgraded to nearly "junk" status. The shock move by the President in firing the Finance Minister and, replacing him with a parliamentary backbencher, with little experience in matters financial and a complete novice, further strains a troubled economy. It is therefore necessary that there is some policy certainty in respect of economic and fiscal issues and that, the government has to intervene decisively, in this regard.

\section{Scope for Further Research}

There is no doubt that there are grounds for further research as concerns the perils of the fiscal and economic crisis in South Africa. This will or must be undertaken as follows:

More work has to be undertaken in this regard by other researchers.

$>$ In addition the research must be conducted by economists and fiscal experts.

$>$ By the same token the outcomes of this research or narrative will require to be tested against the unfolding economic and fiscal crisis, and the development realities that confront South Africa, in this stage of its democratic development, after 21 years of freedom and liberation.

$>$ The effects upon development in South Africa would have to be unpacked in terms of the February, 2016 Budget that will be presented to Parliament by the new Minister of Finance.

$>$ It has to be determined by research whether, the Minister of Finance will be via his February 2016 budget, be in a position to revise his envisaged estimates for economic growth, towards an upward spiral and, place South Africa on to the road of fiscal and economic recovery and stability.

$>$ It will have to be determined by such research, if any inroads have been made by the ANC led government in stemming the tide of economic and fiscal mismanagement of the economy of South 
Africa.

$>$ The study must allow for a projection of intervening strategies that must be put in place by the democratic government, in dealing with the massive corruption that has become endemic in South Africa; as to how it will deal with political patronage, an inefficient public service and its growing wage bill, and so on.

$>$ It would be imperative that government curbs wasteful expenditure and its propensity to spend without the necessary checks and balances and comply with the rule of law, and the Constitution of the Republic.

$>$ Of utmost significance will be to determine as to how South Africa could reduce borrowing and address fiscal deficits, in order to attempt to place the economy into an equal footing and avert the economy to be declared a "junk" economy by rating agencies.

$>$ On the other hand, it will be necessary for new research to determine if the government will introduce policy interventions and, hasten economic growth, decrease high unemployment rates, lessen poverty and, deal with untenable inequality as recommended by rating agencies.

$>$ In so doing the approach that could be used is to invoke classical research approaches and methodologies by a clearly defined set of objectives and, to develop a sound hypothesis to undertake the aims of such a study.

$>$ In addition a sound literature review would have to be undertaken in order to test the developed hypothesis, in terms of primary and secondary data that must emanate from the study.

$>$ Lastly, all of the above would allow for researchers to draw finite conclusions and make applicable recommendations.

\section{Market Reaction}

The rand fell almost 2 percent to the dollar, whilst the dollar strengthens and there is a possibility of the United States increasing interest rates very soon. The rand is now trading at plus/minus R14.50 to the dollar. Any increase in interest rates in the United States will drastically affect South Africa. This has led to the Finance Minister slashing South Africa's growth trajectory in his mid-term budget from 2 percent to 1.5 percent this year and the situation will worsen in 2016 and 2017. This signals a precarious situation for the country, in that, falling tax revenues would put pressure on government debt in the years that lie ahead. This is further exacerbated by the ongoing reality of lowered investor confidence because investors are looking for certainty and signs of economic stability. South Africa is now on the road of economic ruin on the basis that it is becoming a riskier investor destination. Investors therefore, prefer leaving their capital in less volatile and friendlier investor countries, especially the G-3 markets of Japan, the United States and the European Union, in spite of the fact that they offer lower returns. In other words the reality for investors is the issue of politics lead economics.

\section{Slow Growth}

The Finance Minister (Business Report, 2015) stated that the "slow growth environment was in part a consequence of the global slowdown but also reflects South Africa's energy constraints and the structural weaknesses in the country." However, it goes beyond his explanation, in that he did not factor into his equation increased borrowing, large public sector wage bills, the looming water crisis that has befallen the country, the issue of drought and the failing agricultural environment because of government ineptitude, the increasing protests, wasteful expenditure, an inefficient and unproductive public bureaucracy, the mining crisis, increasing poverty, rising unemployment and the huge inequality that permeates the South African landscape amidst a host of other variables including endemic corruption. All of this points to the fact that without stronger growth which must be exemplified by policy certainty, the revenue trend would remain totally muted, which signals that if revenue does not grow, expenditure increases could not be sustained. Electricity supply constraints damage industry and business, puts paid to government's lofty ideals of industrialization; falling commodity prices and lower confidence levels have now led to growth forecast being lowered and drastically revised. It bodes ill for the country as an emerging market. On the other hand limited employment growth and household income constraints are holding back consumption. In this regard the Business Report (2015) states that "China, which is the biggest purchaser of South African minerals and the country's biggest trading partner, posted its weakest quarterly economic growth since the global financial crisis of 2009. The obvious and very serious reality of South Africa's mining sector reflects a contagion that has spread as shown by the falling demand which appears to put a squeeze on the remains of a critical sector in respect of providing jobs to thousands of low-skilled South Africans. 
Given the above scenario political and economic analysts maintain that the country requires a minimum of a 5 percent growth, if it wants to make a meaningful dent in unemployment, but this seems a far cry given the abyss that South Africa sits in over the last several years and the situation is further deteriorating. In other words it projects on the inability of government and the weakness in policy responses to the multitude and myriad of socio-economic challenges that stymie growth, since the ushering in of democracy post 1994.

\section{Rising Debt}

All of this points to the fact that in spite of government adopting a package of fiscal policy measures, it is more talk than action and as things stand, the government will not be in a position to maintain the health of public finances and thus, it would continue to borrow thus placing the country into a fiscal quagmire. The Finance Minister forecasted that "gross public debt was 49 percent of gross domestic product (GDP) in 2015/2016, and would reach 49, 4 percent of GDP in 2018/2019 and 45, 7 percent in 2019/2020" (Business Report, 2015). This is playing to the gallery and is wishful thinking given the fiscal and economic crisis in government and its inability to stem the tide. At these levels and projections, South Africa, will face a severe crunch, greater unrest and above all more scrutiny by investors and rating agencies. The situation looks very bleak for the country because of poor fiscal management and the propensity to increase spending on unnecessary line items within the budget and, its failure to home in on errant departments in respect to wasteful expenditure and overt under-spending and the escalation of public servants salaries. "The budget deficit will reach 3, 3 percent in 2016, wider than the 2, 6 percent predicted in February of 2015 and will swell to 3.2 percent in the following year, up from 2, 5 percent according to the Finance Minister" (Mid-Term Budget Policy Statement, 2015). The problem is due to the fact that the government is unwilling to cut the public sectors wage bill, reduce the number of departments and shrink the cabinet. Thus the country sees an invidious position of a sharply reducing fiscal space to maneuver and thus the contingency reserves had been sharply reduced and thus social priorities have been overtly compromised. This is exemplified by the all-embracing fact as pointed out by the Minister that "the R5billion contingency reserve for 2015/2016 was consumed by a rising wage bill for public servants to manage the shortfall being experienced." This is a precarious scenario and government just does not have the answers to address this swelling unproductive 'monster.' He further added (2015) that "the projected reserves of R15billion and R45billion in the outer two years have been cut to R2,5 billion and R9 billion respectively." These shortfalls in compensation budgets have very serious consequences for public finances, absorbing resources that had been set aside for other more pressing priorities. At another level in 2015/16, "gross tax revenue has been revised downwards by R7, 6 billion as a result of weak performance of corporate income tax collection in the year to date due to the steep decline in commodity prices and the slowdown in economic activity the South African Treasury indicated" (Treasury Bulletin, 2015).

Given the downward spiral of the economy and the fiscal crisis government is seriously considering overhauling the tax system, particular corporate income tax and Value Added Tax (VAT). This would be a recipe for disaster because South Africa and South Africans are already over taxed because of government inefficiencies and the propensity to over-spend, exacerbated by overt and endemic corruption. If this is done, it will drive investors away and add to South Africa's fiscal and economic quagmire. On the other hand the raising of VAT will have very serious repercussions on the majority population that is poor and will increase poverty and the possibility of increased protests and greater turmoil. According to Annabel Bishop, (2015) Investec's chief economist "the latest medium term budget was poorer than expected as far as fiscal metrics go, with fiscal slippage over the period 2016/2017 to 2018/2019 in evidence as the budget deficit widened and the projection of gross loan debt climbed to 49 percent this fiscal year from 47 percent, and elevates to 49, 4 percent of GDP by 2018/2019." It would therefore be difficult for South Africa to adhere to fiscal consolidation.

\section{No Surprises as Forecasts are Revised Down}

Goolam Ballim (2015, p. 21) Standard Bank chief economist stated that the mid-term budget shows "the continued delinquency within Parliament threatens the institutionality of a critical democratic institution. It represents a social expression of a broader financial strain that South Africa has experienced as a function of lingering weak growth, high unemployment and under employment as well as slow movement in the repair of South Africa's historical imbalances." However he further stated that "there is nothing in the mid-term statement that showed that the Treasury have its antennae on the ground to pick up the edginess of the population and the dying pulse of the country's economy." In other words the Minister of Finance missed an opportunity to bring about radical policy interventions to stimulate the economy. It would have been the right time to announce a reduction in state expenditure. The Finance Minister said he was seeking advice about the wealth tax. In our view South Africa already has wealth taxes in the form of capital gains tax, donations tax and estate duty. It would be a mistake to introduce a wealth tax given the very narrow tax base in a country that is already over 
taxed. The economy is in shambles, students continue to protest about sharp fee increases and the government has relented by not increasing fees for the 2016 academic year. It goes beyond the fees issues and government is finding it difficult to raise more than R2, 6 billion to fund fees in 2016, let alone find R30 billion per year to fund free higher education, which is a non-negotiable demand by students. This is a call across the colour line and shows a unity of purpose because, it goes against the grain of the Freedom Charter which states that the doors of learning shall/will be open to all. Education is a public good and given the history that South Africa comes from, it should not be free for the poor alone, who make up about 85 percent of all students, but higher education should be a right and free for all citizens, irrespective of race. It will be a futile exercise to ask less than 15 percent of so-called rich students to pay and then also ask the private sector to fund education in the country. The ruling government is trapped in the quagmire of the continued promises, it has made to the country and, it appears that it cannot stem the tide of resistance to agree to free higher education in totality.

On the other side of the equation is the reality that there is the 9600 MW nuclear programme to which the President has committed the country and, there is the National Health Insurance system (NHI) which has been policy and has begun implementing the first phase without sufficient resources and would run into billions of rand for purposes of universal health coverage that is long overdue. Whilst all of this goes on and on, the inept bureaucracy with its more than 1,2 million public servants have been granted R64 billion in pay increases over the next three years. Coupled with this is an inefficient and loss making state owned enterprises that are constantly bailed out by government. There is no doubt that the Finance Minister will struggle to get the deficit down, as promised. Government has to stick to spending ceilings and not allow fiscal slippage and must be on the road to fiscal consolidation, because the rating agencies are at the door to downgrade the economy to sub-investment grade status. This is an extremely tall order and requires a clear sense of priorities. The opinion in Business Day (2015, p. 12) states that this means that "improving outcomes from the vast amounts of money government allocates to education and health. It means spending better, not just more, and it means setting out a clear strategy for how issues such as nuclear or state-owned entities will be tackled and financed". As things stand there is no plan to achieve this, much to the peril of the nation.

\section{Gloomy Economy}

The Reserve Bank of South Africa sees dark clouds as key indicators slip. It said that the decline in South Africa's economy in the second quarter exemplifies this gloom. Data released by the Reserve Bank (Business Report, 2015, p. 1) indicates that the "leading business cycle indicator of the Reserve Bank slid to a six year low in August, signaling the economy might already be mired in recession. The Reserve Bank governor compounded the Minister of Finances difficulties by stating that the economic growth outlook was extremely fragile." Generally, it is highly unusual for the governor of the central bank to comment on the economy on the eve of the mini budget. This is the reality and both the Finance Minister and the government must view this as the truth and make serious strides to intervene decisively. There is weak private sector investment into the economy as the platinum price shows since the beginning of 2012 and the 25 percent drop in iron ore prices. Given this situation the country has to look at its domestic policies that undermine exports and to counter the favourable impact of depreciation. The Minister must be compelled to explain how government will raise sufficient tax revenue in the face of low growth. Another serious issue is the exchange rate against the dollar and this is decisively a significant risk to domestic inflation outlook, with implications for the pace of domestic policy normalization. "The gloom of the South African economy continued to hurt the poor and the country as a whole when on the 19 of November, 2015 the Monetary Policy Committee of the South African Reserve Bank announced a further 25 basis points increase in respect of the repo rate, which now stands at 6.5 percent whilst individuals borrowing from commercial banks will now have to pay 9.5 percent interest (SABC News; ENCA News, November, 2015). This was introduced in order to bring about price stability and to cushion the Rand which is now trading at R14.00 to the dollar. This intervention strategy is too low to cushion the Rand and will not bring about price stability, but in reality will push up inflation and allow food prices to further escalate. This will hurt the predominantly poor population as living costs rise and will hurt the economy even further. There will be no Christmas cheer for the poor. It was a bad move by the Reserve Bank and ill-timed, as the economy further slides into oblivion and nearer into recession and possible 'junk' status, as rating agencies will soon scrutinize South Africa's fiscal policies and its economy as a whole.

\section{Delays in Investment}

Dineo Faku (Business Report, 2015, p. 1) points out that "more than half of South African firms are withholding investment because of the uncertainty about the economic outlook. Grant Thornton International Business Report (2015) found for the third quarter that 52 percent of businesses confirmed that uncertainty about future political direction was affecting business decisions." This could mean many companies are sitting on large 
amounts of cash, looking for more stable times. The political situation has to improve first before companies have the confidence to invest in the domestic economy. Business is investing less because government policies are contradictory and the uncertain macro-economic environment and the politics that encompass South Africa. On the other hand labour has been problematic for a long time and government has to intervene by making investor regulations friendlier. This is also exacerbated by poor government service delivery which impacts directly on private businesses. "The greatest concern for business owners is basic utility services (water and electricity supply) with 88 percent of businesses affected by this serious reality" (Faku and Khuzwayo, 2015, p. 1). The table/graph below show the net percentage of businesses expressing/expecting (next 12 months) in terms of optimism in economic outlook.

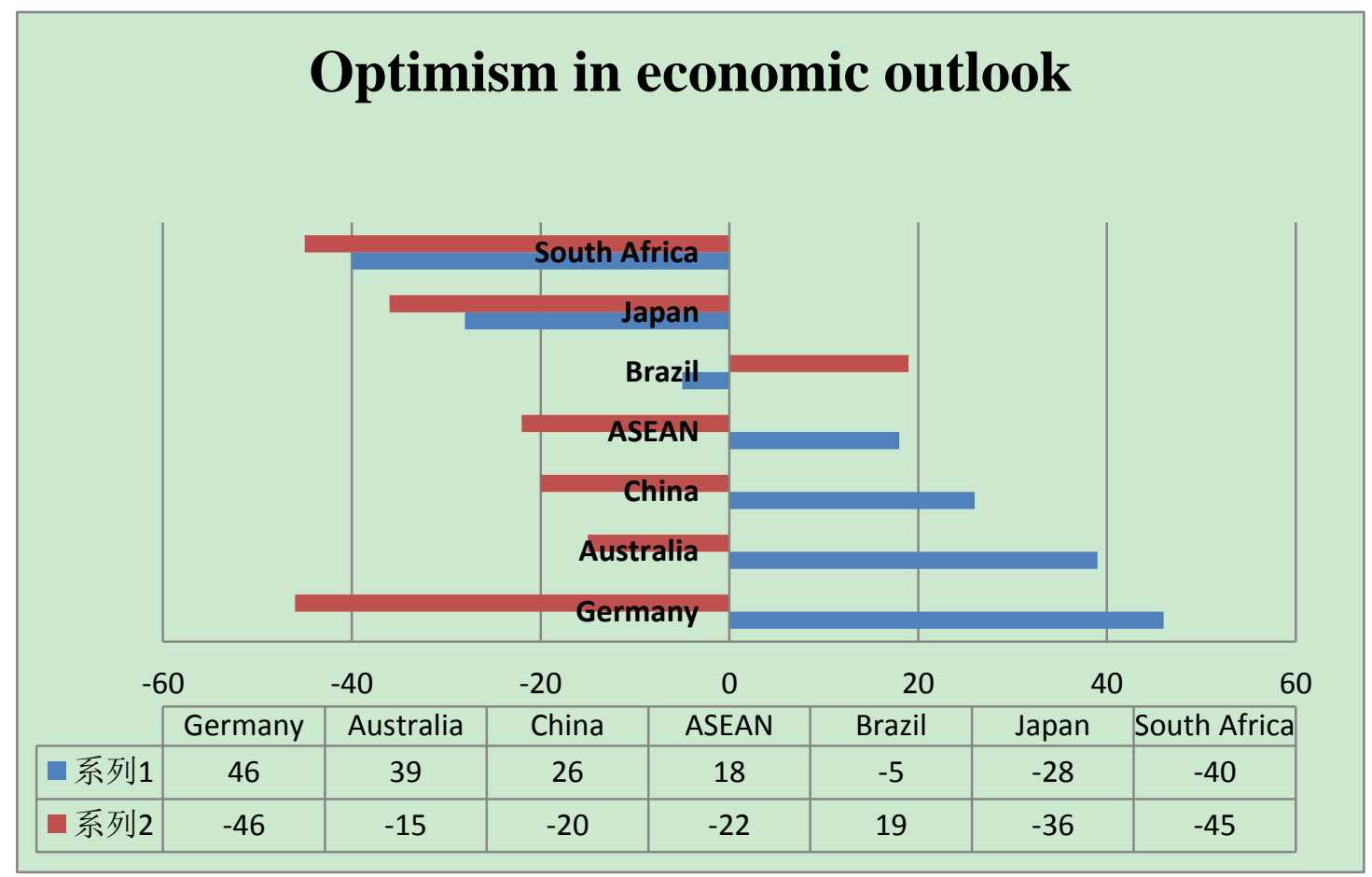

Figure 1. Optimism in economic outlook

Source: Grant Thornton IBR Q3 2015, Business Report.

\section{Cut the Fat Rather than Hike taxes}

Opposition parties have said that the Finance Minister should have committed to cutting the fat and it will be difficult to see how the minister will narrow the budget deficit, stabilize public debt and rebuild fiscal space. They further indicated that a medium term budget policy statement is not about balancing books but also lifting the economy out of the low growth, high unemployment spiral" (The Star, 2015, p. 6). The Democratic Alliance (DA) the largest opposition party stated that "selling off or leasing state assets to raise revenue, reducing the size of the cabinet and privatizing or part-privatizing "zombie state-owned enterprises" could help the government to increase its revenue" (The Star, 2015, p. 6) The Inkatha Freedom Party (IFP) and the African Christian Democratic Party (ACDP) hold the same views as the DA, but added that they do not support increased taxes. All opposition parties stated that the answer lies in economic growth premised on the speedy implementation of the National Development Plan (NDP) and addressing constraints to economic growth, such as the power crisis, labour unrest and infrastructure constraints and dealing with the real water crisis and drought, coupled with the failure of agriculture. The Economic Freedom Front had only one issue or comment and that was that the government must provide a comprehensive funding solution to the university fee crisis (The Star, 2015, p. 6).

\section{Funding Higher Education a Headache for Government}

The zero percent student fee hike announced by President Zuma is causing a headache about where the money will come from, with the trade union movement calling for a wealth tax while the government considers a surplus in the inefficient and bloated sector education and training authorities (SETAS). Universities according 
to Craig Dodds and Don Makatile (2015, p. 6) state "that they are sitting with surpluses and cash reserves and some have invested elsewhere. These accounts must be audited in a transparent process and that such information must be placed in the public domain" Any interference on these surpluses will be unjustified because education is a public good and must be funded by government. On the other hand, is the reality that higher education could be lowered to the lowest common denominator and to the detriment of the country? On the other hand introducing a wealth tax is not the answer in an already highly taxed country with a very low tax base. The African National Congress (ANC) does not have the answers as to where the money will come from. The country sits on a time bomb and all and sundry have opinions that do not solve the problem at hand.

\section{Economic Dark Clouds Gather}

The outlook for South Africa's economy is becoming bleaker, with consumer confidence plunging to the lowest in more than 14 years and in reality it has reached a level of minus 15, which was the index's largest drop since 2008 at the height of the credit crisis." (Khuzwayo, 2015, p. 1). Domestic consumer expenditure is closely linked to the current account which has a shortfall of 4,8 percent of gross domestic product. It is only the second time since the advent of democracy that the index has dropped below the minus 12 index points. Consumers are feeling pressure from all angles, due to substantial household debt burden that has built up during the past decade. The short term outlook of the South African economy is somber amid an environment of weak global demand and expected interest rate increases. The latest indicators show that the wheels are coming off the economy. According to Khuzwayo $(2015$, p. 1) "new vehicle car sales have fallen by 4.8 percent year on year to 50251 units according to the Department of Trade and Industry. Petrol prices have risen R3.46 since February, while food price inflation will soar because of the effects of the drought and the maize price hike. On the other hand according to the Reserve Bank, the ratio of household debt to disposable income increased to 78.4 percent in the first quarter from 78 percent, while the debt services ratio rose to 9.4 percent from 9.3 percent over the period."

Growth in real spending on durable goods decelerated from an annualized rate of 5.3 percent in the fourth quarter of last year to 1.1 percent in the first quarter of this year-the lowest rate of increase since the second quarter of 2009 (Khuzwayo, 2015, p. 1). It is therefore obvious and does not require Solomon's wisdom to state that the consumer rating of South Africa's economic prospects was currently at the lowest since the 1992/1993 recession. The issues of xenophobic violence in April of 2015, the increase and fluctuations of petrol prices, higher debt service costs and rising unemployment rates has eroded consumer confidence. In reality, consumer confidence levels had declined sharply across all the country's population and household income groups in the second quarter, but the fall was particularly large for low income households.

\section{South Africa Caught between the Yuan and a Hard Dollar}

South Africa is caught up in the crossfire of a weakening Yuan and a strong dollar. Tough conditions have befallen the Chinese economy and it has thus taken drastic measures by devaluating the Yuan. It devalued the Yuan by 1.9 percent and further devalued the currency by 1.6 percent and then to 1.1 percent. This resulted in markets responding negatively. The rationale on the part of China was that it indicated that it wanted to move toward a more market-determined exchange rate. Lisa Steyn (Mail \& Guardian, 2015, p. 1) said that "the MSCI Emerging Markets Index plummeted to its lowest point in four years. Global stock indices declined. South Africa's Johannesburg Stock Exchange (JSE's) all share index closed at 3.16 percent lower and the Rand traded at R12. 87 a fourteen year low. South Africa like other emerging markets is at the cross roads of a weakening Yuan and a strong dollar. The latter is expected to strengthen further once interest rates rise in the United States. All of this has drastically affected emerging markets, including South Africa. It is obvious that this signals that things are worse in China than expected, or than what official numbers are saying. In this regard Lisa Steyn points out that "Floating exchange rates, however, have been the norm in many countries since the 1990's and a move in this direction was the right step for China. Its move to a consumer economy means it can no longer control demand and supply components as it had in an industrial economy. The devaluation shows a focus on trying to fix exports. It also boosts growth." Naturally, a weaker Yuan could make the United States Federal Reserve think seriously about raising interest rates because emerging markets have already lost investment opportunities, which has been placed back to the United States. In the face of continued devaluation of the Yuan the US will be the biggest loser because the dollar will continue to be relatively strong, hurting its exports.

According to Lisa Steyn (2015, p. 1) "What the Chinese currency weakness introduces now is more fears of deflation and the US will import more deflation. It is therefore not good news for them and perhaps the Federal Reserve will have to hold back on rate hikes and to wait and see how this plays out." The downside to all of this currency-wise, is for Asian countries competing with China, such as Korea, Taiwan and Vietnam. There is a slight risk according to Christensen (In Lisa Steyn, 2015, p. 1) for South Africa's exports to China, because it 
could become less competitive, but China needs more monetary stimulus to recover. This would stabilize export prices and export growth.” According to Nomura (In Lisa Steyn, 2015, p. 1) in terms of emerging markets the Rand remains the nexus of Fed, China terms of trade and China devaluation themes in our region." There is indeed further scope for Yuan weakness, which will bring about pressure on the rand-dollar rate exchange rates. This has already happened with the rand reaching R14. 62 to the dollar. In real terms R15.00 to the dollar, given bank charges?

The market shows that emerging markets performance is most disappointing and has not yielded the results expected in terms of growth and investment. These issues according to Lisa Steyn $(2015$, p. 1) "faced by emerging markets are more pronounced in countries with current account and fiscal account deficits, such as South Africa. South Africa's economic fundamentals have deteriorated. Stability will take a long time to come for South Africa. Other emerging economies, such as Russia and Brazil, with repo rates of 11 percent and 14.25 percent respectively, are struggling with structural problems and hike interest rates to curb currency weakness. Many of the retrenchments will be in the South African steel sector because mills cannot compete with cheap imports from China." In addition to all of this domestic issues have also hampered South Africa's economy and the situation is worsening. The South African Reserve Bank opted to increase the repo rate by 25 basis points to 6 percent and was based on upside risks to inflation and the vulnerability of the Rand. In so doing it spoke to the gloomy picture of growth, inflation and the sliding Rand. The tone and focus of the Reserve Bank makes it clear that, it wants to try and 'normalize' rates, but at a modest pace.

\section{Fiscal Policy and Data Shows that South African Debt is growing at an Alarming Speed}

Given the growing need to monitor debt following the 2008 global financial crisis and the differences in government debt, the Bank of International Settlements (BIS) a reputable source of primary data, according to Lesiba Mothata (Business Day, 2015, p. 11) states that:

$>$ "Governments worldwide adopted a Keynesian response to the global financial crisis through expansion of government expenditure, which has caused government debt levels to soar.

$>$ Countries hardest hit in the developed world saw fiscal deficits increase and GDP stall. This led to prolonged expansion of government debt-to GDP ratios well above their historic means. On aggregate, for developed economies, debt to GDP ratios has increased from 50 percent of GDP to 90 percent.

$>$ Despite a huge Keynesian response, aggregate demand globally remains subdued, with potential risks down the line emanating from these rapidly increasing debt balances.

$>$ A similar picture was seen in the emerging world. For the Brics countries, on average, debt levels bottomed out at about 40 percent of GDP before escalating to 50 percent currently. Although widely accepted as a plausible framework for grouping these countries, differences remain and analysis of debt on an aggregated Brics basis (Brazil, Russia, India, China, South Africa) masks a lot of detail.

$>$ The response to the crisis of the five Brics countries has differed. China with its very large savings pool and deep pockets of capital in foreign exchange reserves ( $\$ 3.8$ trillion) and sovereign wealth funds (it has five worth $\$ 1.7$ trillion), has added moderately to its government debt balances. China has grown its government debt by only 4 percent of GDP since the Lehman Brothers' collapse.

$>$ India which had a large debt stock heading into the crisis (73 percent of GDP), has been on a path to reduce its debt as it could have proved unsustainable-it has managed to reduce debt by 76 percent of GDP.

$>$ Wounded by the traumatizing effect of the 1998 debt fault, Russia has maintained a prudent approach to its government debt. Since then it has reduced the level from more than 100 percent of GDP to the current 17 percent. This allowed the Kremlin to buy fiscal space and increase debt levels by 8 percent of GDP in response to the crisis. Debt levels however remain relatively low.

$>$ Brazil, on the other hand, gradually increased debt by 4 percent of GDP, now at 67 percent from the already heady 63 percent before the crisis. Sustainability of debt has become the issue for Brazil, which has been sent into a deep recession and increasing fiscal deficits.

> Accounting differences aside, the pace of South Africa's debt accumulation is most uncomfortable. Following a sharp decline in debt levels from 1994, when government debt bottomed at about 30 percent of GDP, the current climb is soaring and most concerning."

Governments have to reduce debt by earning higher national income (faster growth) or stop spending but in the case of South Africa, government has a vulgar propensity to spend lavishly on issues not required by the 
economy. The difficult issue with debt is that if South Africa does not have the money (greater GDP and tax revenue) it is almost impossible to pay it down without a long and arduous effort to stop spending and live within one's means. "Observation and data reveals that South Africa has become the most aggressive debt accumulator in the emerging world by a significant margin" (Mothata, 2015, p. 11). The best way to reduce debt is to bolster economic growth so that borrowings can be paid down, as was the case during the period after democracy, post 1994. Admittedly, local and global conditions were materially different at that time, but the test is in how growth is going to be put back at the centre of current policy construction. At this time and under the current government leadership South Africa does not have the answers to these vexing and troublesome policy issues in respect of sustained and permanent policy construction in terms of fiscal and economic intervention strategies. Corruption, patronage, a bloated and inefficient bureaucracy and public service together with a myriad of issues including poor leadership deepens the crisis of reconstruction and puts paid to development and does not allow for dealing decisively with poverty, unemployment and inequality.

\section{Finance Minister Delivers Budget under Siege}

As higher education campuses erupted in South Africa and a recession looms Lisa Steyn $(2015$, p. 1) states that experts say the Minister is offering nothing new because there is money and everyone knows it but, it is just being squandered. This causes a discontent between state and society because it is painfully apparent that the Finance Minister delivered a speech that will go down as one of the most irrelevant in history considering high inflation, unemployment and overt corruption that now manifests the state under the present government." Although the carefully crafted policy statement seemed preoccupied with allaying the fears of rating agencies and investors, it did not address the fundamental issues that confront South African society. Growth is low and it is not going to be better any time soon. In reality the ANC remains a populist party and has not made a switch to democratic politics in the true sense, as its power base is slowly being eroded given the discontent being displayed by the ordinary majority Black population and therefore, its aims is to hang onto power through its long past revolutionary credentials. People and especially the youth are not buying into this strategy. Those leading the many uprisings and insurrections within the country are led by the middle class and there are aspirants, desperate to harvest the fruits of liberation or transformation after 21 years of democracy and, the empty promises made by the ANC as the vanguard of the revolution which was achieved in 1994. In spite of fiscal constraints there is a realization by the masses that corruption and wastage are at the core of their frustrations and legitimate demands.

The quality of spending and not just quantity came into focus in the Minister's statement reports Lisa Steyn (2015, p. 1) "with the government intensifying its efforts to improve value received for money spent. This is because the money is not reaching the intended beneficiaries and recipients because of the massive leakage and mismanagement of funds. In other words the continuous budgets presented by three Finance Ministers since democracy in 1994, show that these budgets have not been reflective of the demands of society as a whole and the budgets presented over the last three years have been the same. This is despite the fact that the underlying causes of service delivery protests have worsened since 2012. It is not responsive to the plight of the people at all and there is no real movement to address very serious social issues." The policy statement notes that the government's ambitious policy agenda will require increasing the debt to-GDP ratio over the medium term instead of reducing it as was promised. This will require additional taxes but South Africa cannot afford such an intervention strategy perpetuated year after year by an inept and corrupt government which continues to damage the economy and the lives of poor people and the country as a whole.

What is required by the government in general and not only a 'lame duck' Finance Minister is brave thinking in order to free and save South Africa from debt and joblessness. Can the government give hope to 5.4 million people and especially the youth of South Africa who do not have jobs? It cannot currently because it has no plan, no strategy and no political will to bite the bullet and added to this is the reality that the economic outlook is grim. It cannot be business as usual as the narrative in this paper has consistently pointed out. In 1988 Western Europe alienated many young people and turned them into militant groups that engaged in a series of bombings, assassinations, kidnappings, bank robberies and shoot-outs with the police over three decades points out Sechaba ka' Nkosi $(2015$, p. 4). This has already began in South Africa because of the desperation of the poor, the unemployed, the youth who constantly battle the police in a country riddled already with very high crime rates. It must be remembered that a revolutionary wave not too long ago in the form of demonstrations and protest against the widening gap in income levels started independently in Tunisia and quickly spread to Egypt. For South Africa the lessons should be quite palpable. We saw the unity of students in the most recent \#FeesMustFall Campaign within South African universities. It was a campaign that cut across racial lines independently which the government attempted to infiltrate and dilute, but the writing is on the wall. South Africa will not be the same 
and the government lost ground and will increasingly lose ground in terms of its standing and appeal to citizens, especially the youth and it cannot therefore live on its past revolutionary history to govern without accountability. It would be foolish for the government and its ruling elite to dismiss this growing sentiment against inequality as something that would come to pass. Ka Nkosi $(2015$, p. 4) further points out that "the government will have to change gears and focus on introducing policies that will truly stimulate economic growth and give hope to the majority or face their wrath." This will shape the post 1994 South Africa and business will do well to side with the students and the youth in order to really create a democratic order. All of this government has to understand, could very easily lead to a South African Spring and throw the already fragile economy into an abyss of no return and threaten its very survival.

\section{Government Dipping into Savings}

There can be no doubt that the wage bill has indirectly been a contributor to South Africa's sluggish performance as reserve funds are diverted to bureaucrat's salaries. This has forced the Treasury to look at this overshot in the public sector wage bill over the next three years and, therefore, dig deep into the contingency reserves intended to shield the economy from unexpected shocks, wiping out the R 5 billion allocated for fiscal years 2015/2016 and another R48 billion for fiscal years 2016/2017 and 2017/2018. This means in no uncertain terms that there are very serious structural problems in the country which will stymie growth and hinder recovery. It is becoming totally ludicrous in a developing economy that is confronted with serious problems and challenges that government will want to placate an inefficient and unproductive public service rather than throwing the gauntlet down, with the message that either public servants ship in or ship out of the system, trim the bloated public service and the cabinet, freeze salary hikes, in order to drive efficient service delivery. This is not being done by government in view of the 2016 local government elections because of the threat that the ruling party could lose the elections and, is a ploy to desperately hold on to power. The researchers have no intention to further discuss this vexing issue in the narrative, save to say that this is a move in the wrong direction and, can have devastating effects on the economy of South Africa. All of this is reflected in the table 1 below, which clearly indicates that the wage bill has indirectly limited the rate at which the economy can grow and is a clear indication that the wage bill has indirectly and indeed directly been a significant contributor to the economy's sluggish performance.

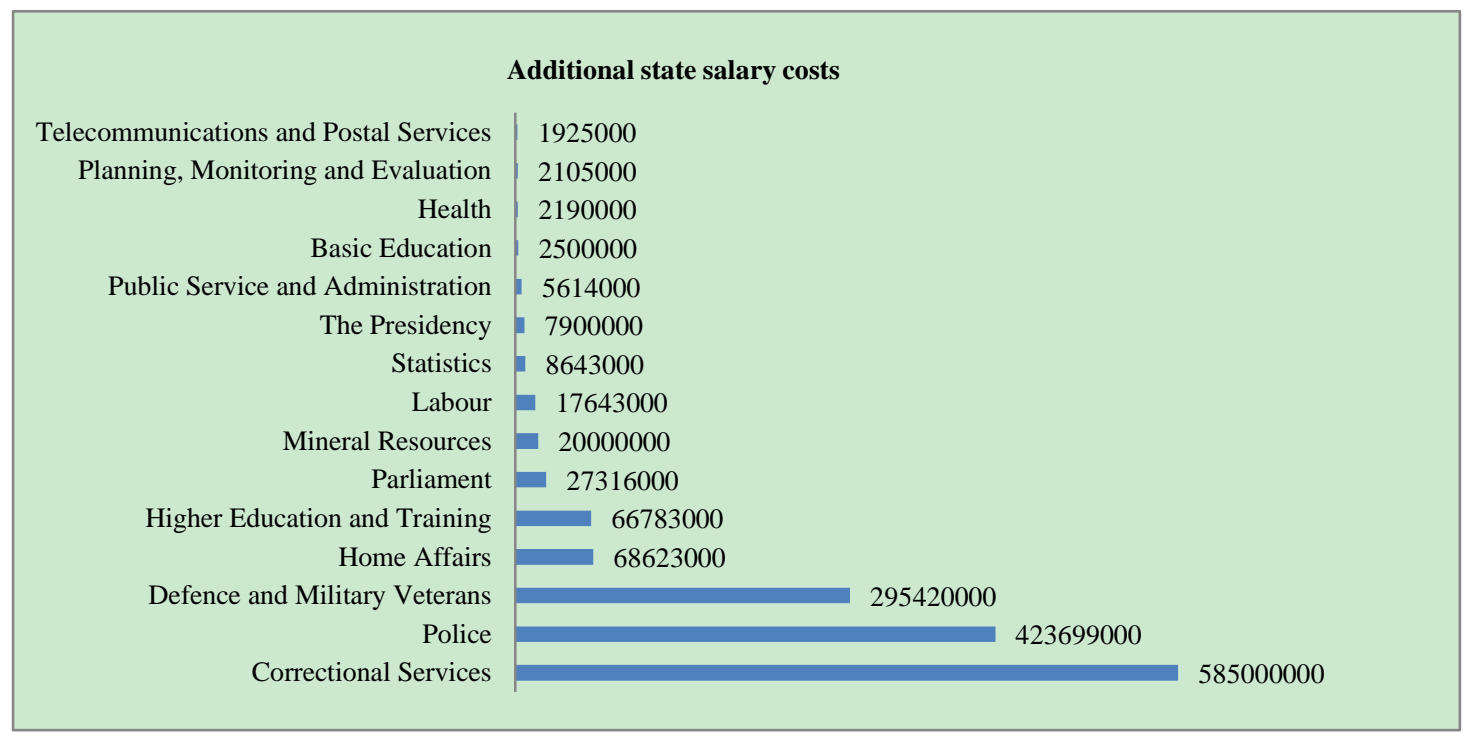

Figure 2. South African government's wage bill and additional state salary costs

Source: Mail and Guardian, October 2015, Adjusted estimates by national expenditure, South Africa "Headed for Tax Revolt".

South Africa faces a 'tax revolt' if the government does not address corruption and spend taxpayers money more wisely, Judge Dennis Davis said at the fourth annual International Economic Law update (The Times, 2015, p. 1). Davis heads the Davis Tax Committee, which has been appointed to re-examine the country's tax system. He said "money spent on excessive wage increases to public servants, bailing out South African Airways (SAA) and the construction of two new universities could have been used better elsewhere. The greater the level of 
corruption, the less we will have tax integrity and the greater the possibility of a tax revolt" (The Times, 2015, p. 1). It is obvious that the government of South Africa is spending more than it is receiving in tax revenue, which has caused a large budget deficit, forcing it to raise personal income taxes in the current fiscal year. This is indeed serious, particularly if it is being raised by Jude Davis of the Davis Tax Committee set up by government. However, the government is not listening and South Africa is slipping more and more into a complete fiscal and economic crisis.

\section{Fitch Ratings Takes Dim View of Mini Budget}

Wiseman Khuzwayo (2015, p. 1) says that given the scenarios that emerged from the Minister's mid-term policy statement on fiscal and economic reform for South Africa, Fitch expressed a dim view because, it is a statement that reflected a marked downward revision in economic growth prospects with a knock-on adverse impact on projections for the budget deficit and government debt to gross domestic product (GDP) ratio in the medium term , which the government did not seek to offset with fiscal policy tightening." The agency said (In Khuzwayo, 2015) that "South Africa's growth and the outlook for the public finances would form an important part of its next review of the country's sovereign ratings." It added that the combination of large budget deficits and lower nominal GDP would keep public debt rising. This points to the reality according to the researchers that with a slowdown of revenue collection to an estimated R35 billion over the next three years, the budget deficit will widen from the earlier forecasts, reaching 3.3 percent in the year through March 2017 and 3.2 percent in the following year. Because of poor government policy to intervene decisively, South Africa finds itself, with an economy trapped in a low growth environment, providing little hope of a significant improvement in the fiscal and debt ratios.

\section{Why Poverty Hurts South Africa More than Brazil}

Calculations by various sources (Editor, Independent, 2015, p. 8) show that "in terms of purchasing power and nominal exchange rates inflation in Brazil has in fact eroded the real value of its minimum wage. The real value in South Africa of the Brazilian minimum wage remains below R2400 a month." By the same token it must be understood that the Brazilian tax and expenditure data include social insurance contributions and expenditures whereas equivalent spending on pension funds in South Africa is excluded. More importantly, much public expenditure in Brazil comprises tax funded subsidies to the pensions of retired civil servants who have a powerful trade union but rank among the rich, not the poor, unlike South Africa. What is learnt from this Brazilian experience in simple terms is the fact that, high levels of public expenditure do not necessarily indicate pro-poor spending. Social assistance and the minimum wage both contributed to a decline in poverty in Brazil, along with strong employment growth. The key differences between Brazil and South Africa are not welfare provision or the minimum wage, but the employment rate which the South African government has failed to action and understand. On the other side of the coin is the reality that poverty is much higher in South Africa because of poor intervention by government to deal with creating permanent quality employment and reducing this inequality. This has to be acknowledged by policy makers and the government of the day in South Africa, and these are some of the reasons why poverty hurts South Africa more than Brazil, which is a Brics partner. There are strong and important lessons to be learnt from the Brazilian experience of development.

\section{President Zuma Says It's Serious}

The inability to create jobs and grow the economy can't be blamed on the African National Congress (ANC), president claims according to Bloomberg and Mabuza $(2015$, p. 1). The president has broken his protracted silence in an attempt to afford some leadership in a country that is reeling and bleeding at almost all fronts. He however, admitted that South Africa has had a serious struggle on its hands in trying to reduce unemployment and boost economic growth. Statistics South Africa released worrying unemployment figures-25.5 percent of the population was jobless in the fourth quarter of the year up from 25 percent in the second. The economy is struggling to create jobs, putting the government's budget under severe strain he admitted. He further said that this cannot be solved overnight. However, the president does not acknowledge that his party the ANC has been governing for over two decades and in reality is slowly destroying the country without a plausible implementation plan to deal with dysfunctionality at almost all levels of government and the public service that, is saddled with very serious structural and policy inconsistences, coupled with endemic corruption on a very wide scale. He denied that student protests in the higher education sector was a sign of discontent with the ANC but were a part of demands to gain equal access to the economy that was still dominated by Whites. This is a constant excuse on the part of the ruling elite to play the blame game in the form of racist attacks on Whites after more than two decades of freedom and liberation and, being in government and not acknowledging that South Africa is straddled and choked by poor government policies, even poor governance regimens and a total lack of 
accountability which sees the country immersed in fiscal and economic inefficiencies and heading towards the doldrums of economic bankruptcy.

Julius Malema according to Bloomberg and Mabuza (2015, p. 2) "accused the ANC of being in bed with White monopoly capitalism and not caring about Black people 21 years after democracy." Zuma said that South Africa is a destination for investment. The president failed to explain how the environment for investment will be created. There is no doubt according to the researchers that the challenges and structural problems together with the vacuum of political leadership in South Africa, is an indication that the country requires new leadership, the time has come for a new breed of leaders beyond their struggle credentials and to this end the environment within the ANC and the South African political landscape not only requires but demands a change in leadership.

\section{Accountability Required in South African Politics}

The continuing service delivery protests, the problems within government structures, the poor performance of government state owned enterprises, the burgeoning discontent of the masses, the uneasiness of the youth, the dysfunctionality of the education and public healthcare systems and the systemic and structural problems because of the inconsistency of government policy, the fragile and broken economy, the fiscal crisis and other pressing issues indicate in no uncertain terms that, South Africa is in a state of paralysis and, all of this requires accountability in terms of the Constitution and the rule of law. "All of these are a microcosm of the larger society, with the same fears, hopes, debts, responsibilities and anger that the rest of South Africa's population has. The issues underpinning the protests are real, even if some of the agitators might correctly be accused of opportunism, and must be addressed" (Mercury, 2015, p. 9). If South Africans of all races agree that there is the next generation of leaders, then we should treat them as such, both in terms of open and frank negotiations, but also in making them accountable for their actions when they break the law and behave in an antisocial manner. The time has come for a change of the ANC political guard for the sake of creating a social contract with all political parties to make South Africa a proud and winning nation and to take the country out of the fiscal and economic quagmire and to deal decisively with poverty, unemployment and inequality.

\section{Kasrils: Zuma Government 'Arrogant, Dictatorial'}

Former intelligence minister Ronnie Kasrils accusing the president's supporters of using state entites such as the South African Revenue Services to conduct personal vendettas against people and former comrades. He said abuse of power, dodgy appointments and demotions, internal power struggles, graft, cronyism and corruption, a lack of accountability and arrogant, dictatorial behaviour, had become hallmarks of the ANC government since Zuma became party president in 2007" (Hofstatter \& wa Afrika, 2015, p. 5). Once issues of this nature continue to undermine democratic principles, the country is confronted with a very serious problem. This is not the only spat that former comrades and some citizens at large have accused the present government of master minding. Not too long ago there was a vociferous attack on the Judiciary of the Republic by the ANC Secretary General undermining its independence and accusing the judiciary of giving rulings against the government. There is no truth whatsoever with regards these accusations against the judiciary because, it had given a ruling that the International Criminal Court (ICC) had issued a warrant for the arrest of President Omar al Bashir of Sudan for genocide in Darfur, but the South African government clandestinely gave him a safe passage, (whilst attending a conference of the AU) out of South Africa with the aid of the President and other Cabinet Ministers, in spite of South Africa being a signatory of the Rome Statutes. So much for South African democracy under the current leadership and government. There are a host of other issues that compromise South African democracy and the interference with the South African judiciary is a signal that democracy is being eroded, with a view of constantly prejudicing the country in the eyes of the world and engineering a way of strengthening the ANC led government to hang on to power. All of this has a negative impact on the country globally and drives investors and business away from South Africa and, which contributes significantly to the already precarious economic climate and the fiscal crisis being experienced in South Africa.

\section{Rising Joblessness a Ticking Time Bomb}

The Editorial of The Times Newspaper October, 28 (2015) states that there is no winner when 5.4 million people are unemployed and the editorial goes on to expand on this issue which is summarized hereunder by the researchers as follows:

South Africa should be afraid, very afraid because the numbers released by Statistics South Africa in respect to unemployment are frightening. Unemployment rose to a staggering 25.5 percent according to this official government agency, but according to political and economic analysts the unemployment figures in South Africa has consistently showed that unemployment is in the region of anything from 40 to 45 percent. The picture on the ground offers little hope as more and more people take to the streets demanding a better tomorrow from the 
government. Students have set the tone by forcing the government to freeze university fees for the coming academic year. The time has come for the ANC-led government, and the opposition led parties and the private sector, to discuss how South Africa can get out of this very serious quagmire. Even more shocking is that the number of discouraged work seekers keeps growing. The country has to stop politicking and find answers to our problems. There is nothing wrong in President Zuma and captains of industry and other organizations sitting down and talking about how to deal with the university crisis, the unemployment crisis, the fiscal and economic problems and other issues, in order to find intervention strategies. But there is everything wrong with our politicians continuing to try to score cheap political points at the expense of South African people.

There are some or rather many who say that our economic fate is sealed and is dictated by outside forces. They say that a change in government is the solution to South Africa's problems. South Africans and South Africa as a people and nation must take cognizance of the situation within the country and hold the government to accountability. South Africa's survival is linked to the economy and as to how we create a better tomorrow. It must be remembered by citizens that the unemployment figures released has faces. They represent hopes and dreams held hostage by an economy that is on its knees. It's time that all South Africans wake up.

\section{Growth Plan must Become a Truly National Project}

In similar vein, The Times of October 29 (2015), in its editorial states that, the South African growth plan must be implemented with urgency through the defined National Development Plan (NDP) as South Africa continues to drift off course, propelled by the twin blows of the global recession and policy uncertainty." The time is opportune for a dialogue and the case of a dialogue with all stakeholders has never been more compelling. The dialogue becomes important for purposes of developing and inclusive prograame to deal with the issues identified in this narrative and to action the NDP which is sitting on government desks gathering dust. Rattled business persons are disinvesting, diversifying abroad or holding on to piles of cash. The pointless squabbles that has made the South African Parliament look like a "circus" fuelled by indiscipline and an ANC speaker that toes the ANC party line and compromises free debate, also does not offer much hope of finding a sustainable solution; neither does a cabinet beset by deep ideological divisions that mirror those in the ANC-led tripartite alliance.

South Africa already has a blueprint for growth in the National Development Plan (NDP), which the ANC has accepted despite fierce criticisms of some of its neo-liberal provisions by the party's alliance partners (SACP, Cosatu (the Federation of Labour Unions) and other formations. The plan was developed by former Finance Minister Trevor Manuel and current Deputy President Cyril Ramaphosa who were the architects of the NDP. Lacking is clear direction on how to implement the growth plan, a workable timetable with specific targets, and broad societal commitment to its aims and objectives. It becomes a non-starter if government continues to appease the labour Unions or is afraid of antagonizing them as the plan is almost four years in the making, time is slipping bye and the economic and fiscal crisis, including cheap and unreasoned politics exacerbates its implementation. The NDP has to be fast tracked and there has to be a frank and open dialogue with all stakeholders. This would allow for reigniting the ailing economy and creating the millions of jobs that are so desperately needed. The development plan will have to evolve from being a government programme and become a national project.

\section{South Africa Is Losing Its Way}

Vusi Gumede (2015, p. 19) states that "Policy paralysis and compromises mean inclusive development continues to elude the country. By implication South Africa must and should take full charge of its destiny. The key role player is therefore government in this regard. However, for South Africa the opposite seems to hold. Instead of taking full charge and therefore a fundamental question arises-Why has inclusive development been elusive since 1994"? Development, simply put involves socioeconomic progress or the improvement in people's wellbeing. Countries go through different stages of development. It is generally understood that development must involve people that need it; people must have choice for their livelihoods, as Amartya Sen put it. Gumede (2015, and Karodia, 2014) state that, similar to Sen's "development as freedom" notion, Frantz Fanon conceptualized development as associated with socioeconomic freedom and Fanon goes a step further-he also approaches development from a pshchosocial perspective, which would view the political independence South Africa is said to have attained in 1994 as a facade because the land, for instance, is still in the hands of a few including the new elite, hence the inevitability of elusive development." For South Africa, the debate about development also has to deal with social and economic inclusion. Viewed from this perspective, inclusive development has been shallow in post-apartheid South Africa.

South Africa's economic performance has been pedestrian relative to many comparable countries such as Brazil, India, Malaysia and Botswana, and the local economy has performed below its potential (Gumede. 2015, p. 19). 
The challenge of achieving inclusive development has been exacerbated by factors such as unstable regulatory regime, labour demands, deindustrialization and capital flight, among other obvious issues already discussed in the narrative. A stable regulatory regime is a sine qua non for securing the confidence of local and foreign investors. Given the unpredictability in South Africa over the past few years, long term planning and business projection suffer. This has very serious implications for macroeconomic stability. The increased protests and strikes that have befallen the country affect productivity and hamper development and does the economy a disservice. All of this given the scarcity of money available, the state cannot implement redistributive policies. "Governments failure to regulate movement of capital has major implications for achieving inclusive development. Liberalization of the capital account and its effect on the balance of payments also predisposes multinational companies to take out money as they please, money that should be used to facilitate an inclusive economy. Government has failed miserably to curb these much needed outflows of capital". To achieve inclusive development, it will be necessary for government to pay necessary attention to these variables, including the need for a robust and inclusive industrialization programme.

Another way of looking at post-apartheid South Africa's development experience is to compare the country's level of human development with that of other countries. Again South Africa performs very badly. The level of human development has not significantly improved since 2000. The Department of Health (2014) states "that the various components of human development in respect to education, healthcare and standard of living, life expectancy declined between 1990 and 2005 whereas gross national income per capita has not changed much since 2010." "Many perspectives of the national liberation movement inform post-apartheid policies in South Africa. These include the 1943 Bill of Rights in the Africans' Claims; the 1955 Freedom Charter; the 1962 Road to South African Freedom, the 1992 Ready to Govern discussion document; the 1994 Reconstruction and Development programme, the 1988 State Property and Social Transformation discussion paper; and the 1996 Constitution of the Republic. Ready to govern is perhaps the most important. If South Africa had stuck to its analysis, it would now probably have better social and economic outcomes" (Gumede, 2015).

The clarity of thought encapsulated in Ready to Govern implies that the society envisaged by the liberation movement led by the ANC, could have been accomplished by now, or to a large extent, if its principles and policy propositions had been followed. On the other hand the Freedom Charter seems to downplay the negative impact of colonialism and imperialism, by giving precedence to non -racialism. This has hindered development and has reinforced the White minority. Many compromises were made that have and do not allow South African society to move forward faster. Gumede (2015) rightfully points out that "a new vision for South Africa's political economy is overdue. The historical experience of apartheid-colonialism and its ramifications should be informing policies that post-apartheid South Africa pursues, so that, it can ultimately become the "nation' that so many sacrificed their lives for. As things stand there is an illogical unsustainable compromise-a compromise between African majority rule and the White minority who hold greater economic power. The ruling party has lost its way given its rich revolutionary credentials and it has compromised the majority Black population, if not all South Africans, including the rising middle-class."

Given the socioeconomic exclusion characterizing post-apartheid South Africa and the high levels of racial inequality, inclusive development continues to elude the country. In short inclusive development has been halted largely by the ruling party's policy paralysis imperatives post 1994 . Without decolonization in land reparations, a stop to corruption, crony capitalism, patronage and all that goes with poor governance and the mismanagement of the economy and the fiscal crisis, South Africa is on the road of destruction under the current ANC leadership within government. In actual reality and in fact, development has actually not even started in South Africa.

\section{South Africa's Economy Downgraded by the Rating Agencies to Nearly “Junk" Status: Cry the Beloved Country}

The narrative outlined a rather gloomy picture of the South African economy and, it appears that, the chickens have come home to roost to hurt South Africa because on the 28 of November, 2015 the rating agencies Fitch and Standard and Poor downgraded the South African economy by one notch to nearly "junk" status. It would now appear that the country requires divine intervention to take it out of the doldrums as the economic situation worsens under very poor political leadership and mismanagement of the economy. The rating agencies Fitch and Standard and Poor warn South Africa of the perils of low growth, because the ratings agencies' views matter to the lenders and institutional investors that South Africa relies on for funding. South Africa, according to Standard and Poor cites lack of economic reform in respect to South Africa's invidious economic position. The one notch downgrade of South Africa's credit ratings had been widely expected. However, the rating change by its larger rival Standard and Poor's ( $\mathrm{S}$ and $\mathrm{P}$ ) which put South Africa on negative watch, came as a surprise to some in the market, and this is a nasty blow for the economy of South Africa. Cry the beloved country for corruption, 
government inefficiency, and mismanagement of the economy; its inability to create quality employment which is shown by escalating unemployment anything to the tune of 25 to 42 percent, rising inequality and increasing poverty, exacerbated even further by load shedding, the water crisis that requires over R800 billion over ten years to repair, the crisis in higher education, increasing political patronage, cronyism and increased level of service delivery protests. The move could see S and P downgrade South Africa's rating to sub-investment grade-"junk" status, within the next 18 to 24 months. That will have severe implications for capital flows, the Rand and for the countries banks and corporate borrowers. "The South African political leadership has to now make some tough choices or wither the beautiful country under the watch of the African National Congress led government. Given how fragile South Africa's position now is, their analysis needs to be closely scrutinized, and the government needs to get the message that the country is on the edge of an economic crisis, unless quick action is taken" (Business Day Editorial, 2015, p. 10).

The issue that looms largest in both ratings is the issue and question of growth. In reality South Africa is in a state of recession. This is denied by the government. The growth position is very low and this topped the agenda of the ratings agencies in terms of their negative rating actions. They are concerned about the weak levels of business confidence and private sector investment. It needs to boost business. It appears that government according to the rating agencies is not serious in this regard. The rating agencies said that "Government policies such as visa regulations and delays to the mineral resources law and prospective plans for land reform and a national minimum wage are not always conducive to economic growth" (Business Day Editorial, 2015, p. 10). The National Development Plan is a non-starter in terms of implementing and actioning it. There are significant risks to the numbers provided by the Minister of Finance and he remains a "lame duck" minister because his cabinet colleagues are not listening, with government's propensity to spend without accountability. Standard and Poor outlined serious concern in respect of the financial status of State-owned enterprises, which shows that they have become a large drain on the fiscus, undermining any flexibility that the finance minister has, in this regard. Government has not tightened fiscal policy in response to weaker revenues. This is a clear indication that, if government does not intervene swiftly, the new Finance Minister will have no room to maneuver, when he presents his national budget in February of 2016.

There is also a range of added negatives including the delays to bringing new electricity capacity on line for the country. This is also due to South Africa's large current account deficit and its vulnerability to difficulties in funding this, coupled with serious labour strife. Many dismiss rating agencies as irrelevant but their views matter to lenders and institutional investors that South Africa relies on for funding. As long as South Africa continues to run high fiscal and current account deficits, it will need international funding in sizeable quantities, and it will therefore need to take ratings seriously, if it wants to raise that funding at affordable rates. Fitch and Standard and Poor's actions should serve as a sharp reminder that the economic mediocrity that South Africa has been sliding into is not just disappointing, but most dangerous. "Junk" status is only a year away because the rating agencies decision means there is at least a one-in-three chance that South Africa will end up with a speculative credit rating within the next year or two, which will raise the government's cost of borrowing, dampen foreign investor appetite for domestic shares and bonds, and deliver a severe blow to the weakening Rand" (Isa, 2015, p. 1).The debt outlook hits currency in South Africa and, in this regard the Business Report, Wiseman Khuzwayo, Bloomberg and Reuters (2015, p. 1) states that after the ratings agencies announced the downgrade "The Rand fell to a record low against the US dollar trading at R14. 66 or R15 after bank charges and nearly R22 to the British Pound. It stands today at R15.66 to the US Dollar and R23.16 to the British Pound. Bonds tumbled sending yields to their highest levels since February, 2014. The downgrade means that South Africa has been reduced to BBB-(Minus) from BBB. South Africa's net gold and foreign exchange reserves were lower at $\$ 40.471$ billion in November from $\$ 41.308$ billion in October." This is a clear indication that the sub-investment grade theme was always about institutional quality and political will to reform. In other words structural reform are not occurring to boost the economy and business confidence. In spite of the criticisms advanced against Rating Agencies Khuzwayo, Bloomberg and Reuters (2015, p. 1) point out that "the global economy has moved on, and although its recovery has become patchy and uneven, credit rating agencies today provide some of the most objective risk assessments of countries and, it is in the interests of South Africa to seriously take heed of this."

Given the political shenanigans within the body politic of South Africa, the country's ratings are likely to remain under downward pressure. It is obvious that South Africa has been hit by a barrage of negative economic data with manufacturing activity plunging to a "six year low last month, falling 2.1 percent year on year" (Isa, 2015, p. 1). The authors do not believe that the shock will hit home and that the government will take this outlook change in the serious light in which it should be taken-this is an economy in trouble. The 2016 local government 
elections will also not allow the government to intervene because, it is obsessed to remain in power and, would use state resources to win the elections, and in so doing will definitely overspend and add a heavy burden to the South African economy. This is the reality that citizens live with and can only turn things around at the ballot box. Given this bleak picture, drought and the current heat wave has become a nightmare for South African farmers and the country, as food prices rise and given the import of the food staple, maize. "South Africa is in the grip of its worst drought since 1992" (Business Report (2015, p. 1) and, this exacerbates the situation and plunges the economy into deeper problems. Only divine intervention will be in a position to help. This is exemplified by the Governor of the Reserve Bank, according to Volgraaff $(2015$, p. 18) "struggling to keep the weakening Rand from fuelling inflation at a time when interest rates are at their highest level in five years and GDP is growing at its slowest pace. Added to this is the possibility of the US Federal Reserve's first rate increase looming on the horizon, in a decade; an event likely to accelerate the capital exodus from South Africa's economy and, therefore the situation and task of recovery becomes more precarious. The Reserve Bank is sitting in a classic stagflationary bind." The problem is not the Reserve Bank but, an ineffective and inefficient government which does not see growth as the biggest crisis in the country. According to Vollgraaff $(2015$, p. 18) "The government's ability to carry out reforms was hamstrung by ideological differences in the ruling alliance." It has to be driven home that South Africa is nearing an economic cliff and must change course in all directions with particular reference to policy certainty and must realize that the billions lost to graft does not inspire confidence. Another shock hit South Africa on the $10^{\text {th }}$ of December, 2015 when the South African Press Association and the general media reported that "South Africa's four major banks were downgraded to BBB-(minus) by rating agencies. This situation places and compounds South Africa's economic crisis, and it is now, in an invidious position of being declared a 'junk' economy in the near future and, borrowing will become all the more difficult and will add tremendous pressure on the country."

\section{President Zuma Fires Finance Minister Nene}

Against the back ground of this depressing narrative, South Africans woke up to the announcement by the President Jacob Zuma on Thursday $10^{\text {th }}$ December, 2015 that he had fired the current Finance Minister. He had only spent 18 months in the post. This triggered a further slump in the "Rand as it dropped by 5.4 percent to R 15 . 66 or R16, after bank charges against the US dollar. It was also announced that the new Finance Minister would be David Desmond van Rooyen, an ANC backbencher with relevant experience or no experience in Finance, with a trail of inefficient management when he was the mayor of Merafong Municipality in the North West Province of South Africa" (Joubert, 2015, p. 1). The announcement was unexpected and places the country into a collision path in respect of fiscal and economic parameters. The speculation is that the President replaced the Minister of Finance without tangible reasons because, the former Minister and some of his staff tried to hold the line of fiscal discipline against rampant state spending and an increasing and widening budget deficit. It is also exemplified by the fact that the former minister refused to allow an expensive deal, to buy the President a luxury Jet for his international travel, given his desire to invoke fiscal consolidation, in times of an economic crisis. In addition, former Finance Minister Nene opposed any bailout for South African Airways which has been run to the ground by the Chairperson Dudu Myeni, a close friend of Jacob Zuma (President) and, is also the Chairperson of the Zuma Foundation. It has also been reported that the former Finance Minister opposed the nuclear deal that has been signed by the President and, is almost a done deal, that would cost South Africa trillions of Rands and, which South Africa cannot afford.

Given the announcement, it is obvious that the President is only concerned about himself and his cronies and, is averse to any criticism of him and some of the impractical ANC policies. The Presidents confidant (Dudu Myeni of SAA) also clashed with the Minister of Public Enterprises and, the former Minister of Home Affairs. Dudu Myeni is an untouchable to the peril of the country. According to the former Premier of the Gauteng Province Shilowa $(2015$, p. 2) "If you wanted proof of what power Myeni wields you simply have to look at the casualty list."

The move of firing former Finance Minister Nene and replacing him with a novice sent shock waves through the political system and that, Nene was taken aback by his removal, and Treasury insiders indicated that the move was political" (Mkokeli \& Paton, 2015, p. 1). This is the first time that someone as junior as Van Rooyen has been appointed to arguably the most important Cabinet position. This has caused anxiety in the investment world as concerns the direction of the economy. This made the former Minister of Finance, Nene a "lame duck" Minister, not out of choice but owing to very trying economic times and, the lack of support from his Cabinet colleagues and the President of the country. According to Mkokeli and Paton $(2015$, p. 1) and the entire South African press and, political commentators "Nene has done his best and was doing a good job and enjoyed the support of the markets, with rating agencies also noting the difficult, but commendable fiscal consolidation path 
he had taken the Treasury through. Plainly put, he was not supported by the President and his Cabinet colleagues or for that matter the ANC. He was deputy to the former Finance Minister Gordhan for five years and, learnt quickly under his stewardship. This would remove institutional memory that South Africa can ill afford during this crucial and declining economic times." The axing of Nene is the beginning of a major reshuffle of Cabinet looms. There is strong speculation that senior Cabinet members would be axed and that the former Minister of Finance is headed for the Brics bank that was set up in October. There is no doubt that the former Minister of Finance Nene has been demoted and will be sent to an inconsequential posting. Cry the Beloved Country as the economy withers. His axing according to Mercury Correspondent $(2015$, p. 2) "is likely to cause a stir in business circles as he had portrayed continuity in fiscal policy, sticking to expenditure ceilings first announced by his predecessor."

While it may be theoretically true that South Africa has the resources to keep running up debt before it needs a bailout, it would now set in motion a chain of events that would bring that risk forward to now (Editorial, Financial Mail, 2015, p. 6). On the other hand Tim Cohen states in South Africa's case that "There is a chess position which has a great name; it's ominous, dark and suggests an uncomfortable future, which is exactly what it is. The word is zugzwang, and essentially what it means is that any move you make is wrong. It's a rare situation that occurs only in endgames when there are few pieces on the board. Zuma and his Cabinet and the ANC have become victims of their advantage of being the move makers." This is further exacerbated by their declining popularity within a complicated political South African dynamic and the economy is at the centre of this problem. In politics, the move making advantage you have in chess lies in being in power. Given the firing of a competent "lame duck" but efficient Minister of Finance creates the big danger that any move Zuma now makes will be wrong, like he did in firing the former Minister of Finance. All of this has very serious political repercussions. It is hard being in power, but much of the position the President finds himself in is self-created. "This means that South Africa under the present ANC led government is undoing all fiscal gains since 1994 and, this is primarily due to the reality that we have too many inefficient and overpaid public servants and the failure to implement a clear growth policy" (Bisseker, 2015, p. 18). The discussion in this paper in terms of the problems that South Africa finds it-self in is shown in the five graphs hereunder as follows and is a synopsis largely of the discussion undertaken in this narrative.

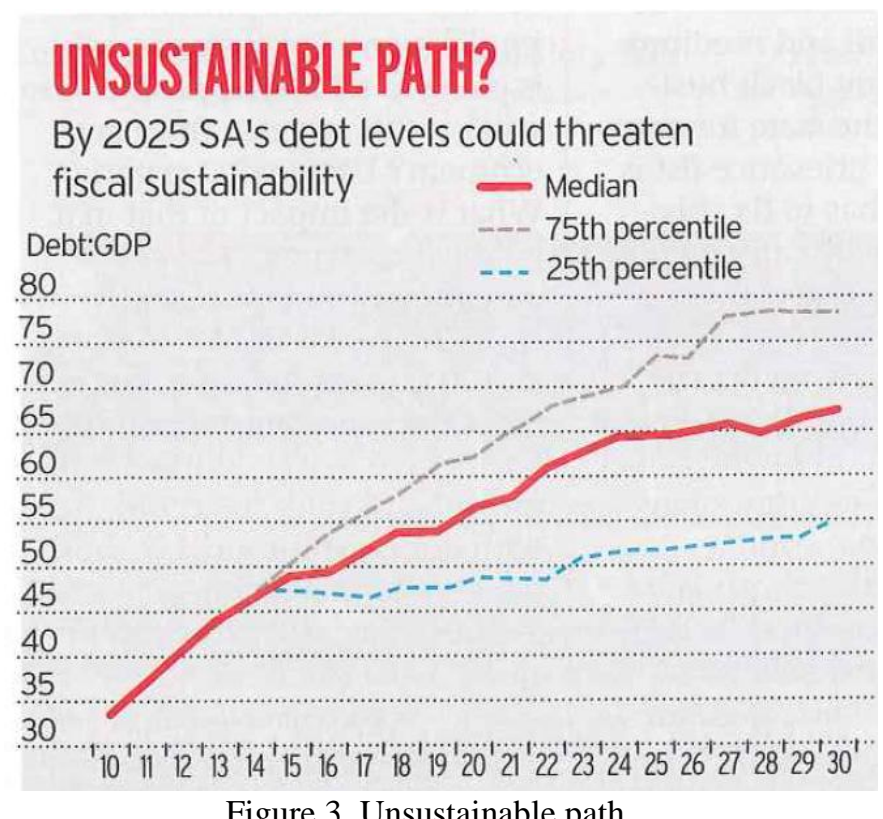

Figure 3. Unsustainable path 


\section{BACK TO THE FUTURE}

By 2025 the interest bill could become problematic $\%$ Interest payments:GDP

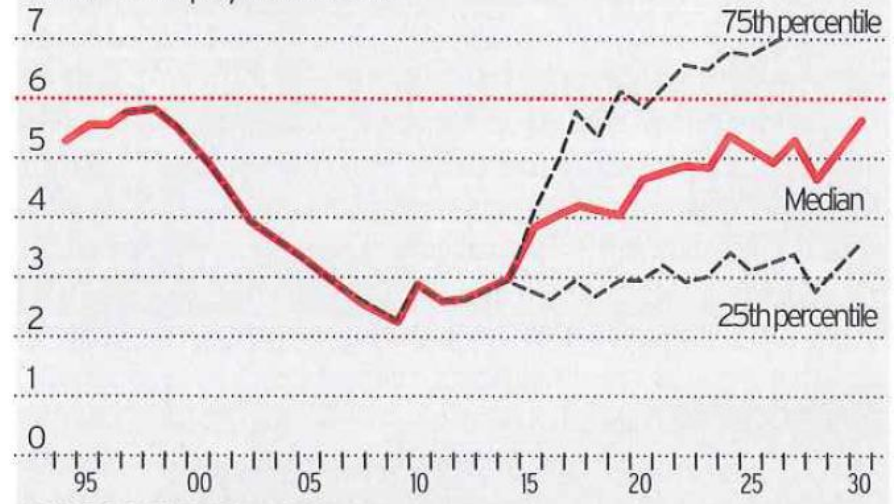

Figure 4. Back to the future

\section{BLOWING THE BUDGET}

\section{Overspending on wages mostly to blame}

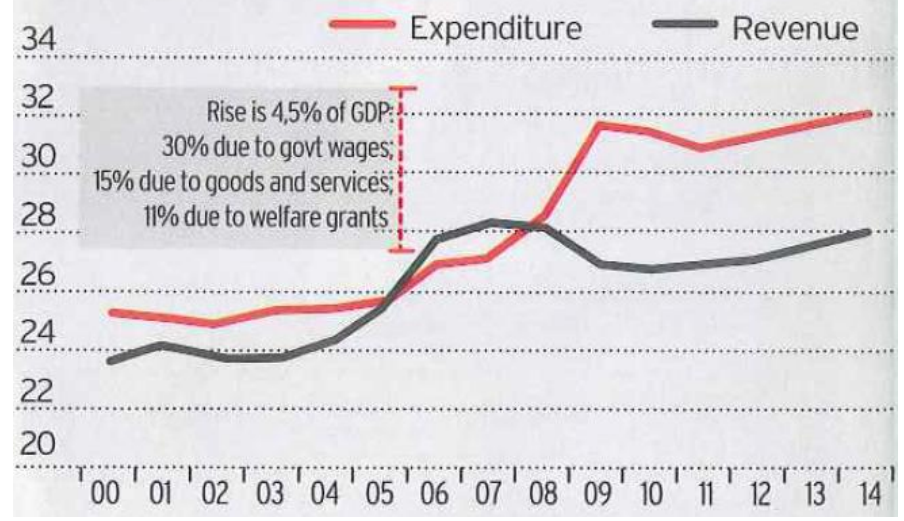

Figure 5. Blowing the budget

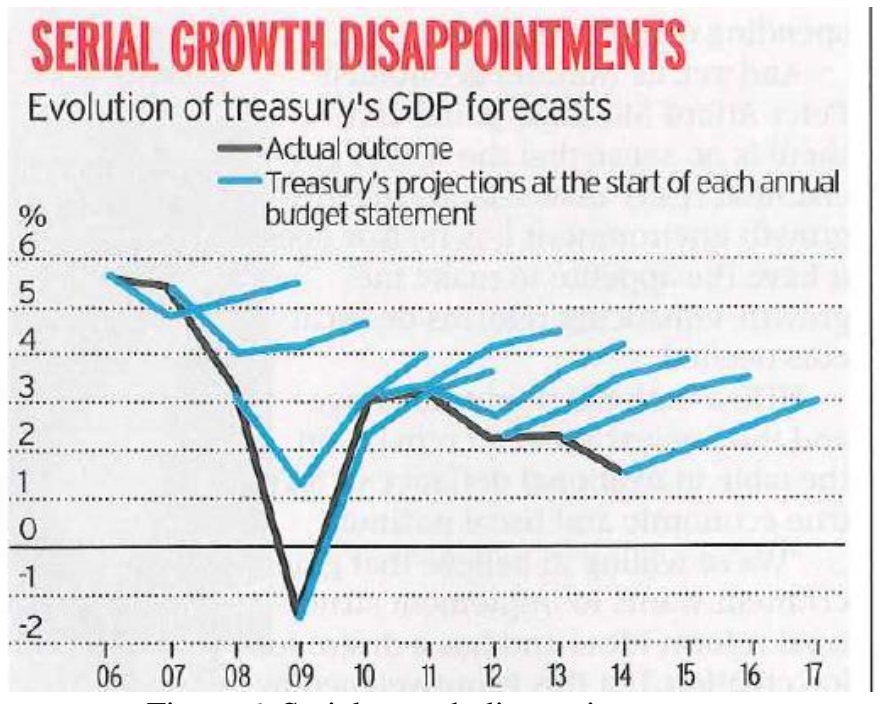

Figure 6. Serial growth disappointments 


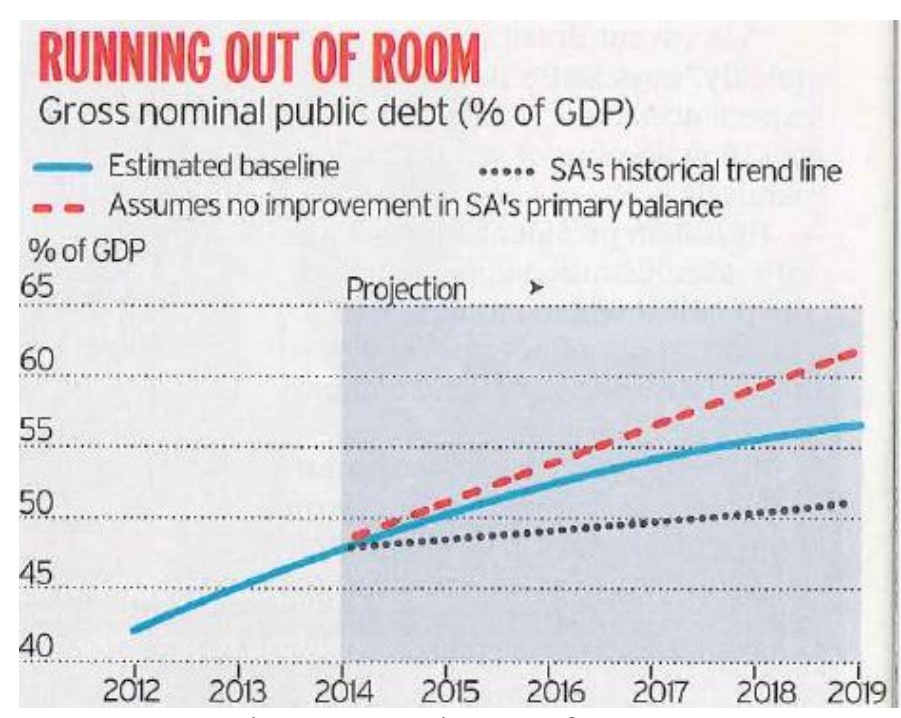

Figure 7. Running out of room

Source: Financial Mail. Republic of South Africa: December 10. Pages 18, 19, 20, 21 and 22.

\section{Conclusion}

There is no doubt that South Africa sits on the abyss of fiscal and economic destruction and as things stand at the moment, it appears that the government does not have the leadership to deal with the issues outlined in this paper. It's time for leadership. Perceptions are terrible. They are intangible; chimeras that taint memories and destroy legacies. The ANC faces a real threat of destroying its revolutionary credentials, if it continues to govern in the manner that it does presently. The ANC led government, must understand that there is a real perception that the ANC is aloof to the needs of the country and the needs particularly of the ordinary citizen and, is willing to use force to protect the interests of the elite.

This perception is fast metastasizing into a believed reality fuelled by a lack of leadership and an over-reliance on the police. Given the morass that South Africa finds itself in as concerns socioeconomic issues, the fiscal and deepening crisis, it's not management that is now required, it is decisive leadership that is now required. The genie has been well and truly loosed from the bottle. All that can contain it now is leadership from the country's highest echelons. Anything else or less would serve only to galvanize dissent, and perception uncontained will turn into self-fulfilling prophecy. South Africa cannot afford this outcome because it will be too frightening and ghastly to contemplate-whatever South Africans may think. Perhaps, given the reality that the ANC led government does not have a strategy to intervene because, it has plunged the country into this morass and chaos, the only solution perhaps is divine intervention or a revolution of insurrectionary propositions. This can be done and achieved peacefully at the ballot box.

The new political elite that took over from their colonial masters the Afrikaners in South Africa's case are driven not by wealth distribution that their manifestos propagate, but the accumulation of wealth in the quickest way allowed within the constraints of the Constitution that, is seen only as a nuisance that can be sculpted away. What we now see in South Africa is in effect "Hellenicfication" (Greece) of the economy, where this regime, like all successive Greek governments, promised everything to everybody who might give them the vote, and binged on the ever-reducing tax base, maxing the sovereign credit facilities on the premise that creditors will forgive. Any positive argument that some commentators are apt to proffer on behalf of the ANC is all about, an opportunist party driven by unfettered greed. One only has to look at what has taken place in Nigeria, Kenya and that beacon of democracy, India, to see how crooked the ruling elite has become, too intoxicated by power to temper the appetite for wealth. South Africa needs a real revolution of the electorate that will vote in real leaders. The time has come or we can only hope for divine intervention. Cry the Beloved Country as it withers away its democratic freedom and revolutionary credentials, and tarnishes and, erodes the legacy of so many stalwarts of the freedom struggle and, the aspirations of so many that laid down their lives for the country, and drives a wedge between the masses of the poor and the ruling elite. 


\section{References}

Ballim, G. (2015). Standard Bank of South Africa's Budget Analysis. Johannesburg, Republic of South Africa.

Bishop, A. (2015). Investec's Round up on the Budget Policy Statement. Johannesburg, Republic of South Africa.

Bisseker, C. (2015). Fiscal Cliff-hanger. Cover Story: SA Economy, Financial Mail, December 10 to 16. Johannesburg, Republic of South Africa.

Bloomberg, \& Mabuza, K. (2015). Zuma says it's serious. The Times, October 29, Johannesburg, Republic of South Africa.

Bloomberg. (2015). Drought and heat wave become farmers' nightmare. Business Report, December 8. Johannesburg, Republic of South Africa.

Budget Reactions. (2015). Economists find little to no surprises as forecasts are revised down. Business Report, October 22, Johannesburg, Republic of South Africa.

Business Times. (2015). South Africa's only solution is rapid growth. Sunday Times, October 25, Background Reading, Johannesburg, Republic of South Africa.

Derby, R. (2015). What South Africa can learn from Nigeria's slide? Sunday Times, Business Times, Editor's View, Background Reading, September 27, Johannesburg, Republic of South Africa.

Davis, D. (2015). South Africa "headed for tax revolt" says judge. The Times, November 6, Johannesburg, Republic of South Africa.

Dodds, C., \& Makatile, D. (2015). Tax hike or wealth tax, R5 billion Seta surplus or education levy? Independent, October 19, Johannesburg, Republic of South Africa.

Donnelley, L. (2015). Wage Pact weighs on Nene's budget. Mail and Guardian, Business, State Salary, October 23 to 29, Johannesburg, Republic of South Africa.

Editorial. (2015). Accountability. Opinion. The Mercury. October 21.

Editorial. (2015). Growth plan must become a truly national project. The Times, Opinion and Letters, Johannesburg, Republic of South Africa.

Editorial. (2015). It's time for leadership. The Star, October 23, Johannesburg, Republic of South Africa.

Editorial. (2015). Nene has work cut out for him. Opinion, Business Day, October 21, Johannesburg, Republic of South Africa.

Editorial. (2015). Rising joblessness in South Africa is a ticking time bomb. Opinion and Letters, October 28, Johannesburg, Republic of South Africa.

Editorial. (2015). South Africa on the brink of junk status. Business Day, Opinion December 7, Johannesburg, Republic of South Africa.

ENCA News. (2015). Parliament of the Republic of South Africa and the South African Reserve Bank Announces a Rise in the Repo Rate. November 19, Johannesburg, Republic of South Africa.

Garow, C. (2015). GDP projections will be focus of rating agencies. Business Report, Opinion and Analysis, October 21, Background Reading, Johannesburg, Republic of South Africa.

Gough, N. (2015). A mismatch in China of jobs and workers. International New York Times, Business, April 22, Background Reading, Hong Kong.

Gumede, V. (2015). South Africa seems to be losing its way. Mail and Guardian, Comment and Analysis, June 12 to 18, Johannesburg, Republic of South Africa.

Hofstatter, S., \& Wa Afrika, M. (2015). Kasrils: Zuma government “arrogant, dictatorial.' Sunday times, October 25, Johannesburg, Republic of South Africa.

Isa, M. (2015). South Africa edges closer to junk rating. Sunday Times. Business Times. December 6. Johannesburg, Republic of South Africa.

Joubert, J. J. (2015). Zuma gives finance minister the boot. The Times, Reuters, December 10, Johannesburg, Republic of South Africa.

Karodia, A. M. (2014). Ongoing Reckless Lending in South Africa Ministers Wish List to End Abuse of Debt. International Journal of Accounting Research, 1(2).

Khuzwayo, W. (2015). Economic dark clouds gather. Business Report, July 3, Johannesburg, Republic of South 
Africa.

Khuzwayo, W. (2015). Fitch Ratings takes dim view of mini budget. Business Report, October 23, Johannesburg, Republic of South Africa.

Khuzwayo, W. (2015). Nene has to walk a tight passage now. Business Report, August 21, Johannesburg, Republic of South Africa.

Khuzwayo, W., \& Faku, D. (2015). Gloomy economy set to vex Nene. Business Report. October 21. Johannesburg, Republic of South Africa.

Khuzwayo, W. B., \& Reuters. (2015). Rand falls to record low after rating cut. Business Report. December 8. Johannesburg, Republic of South Africa.

Leoka, T. (2015). Economic power or political power. Sunday Times, Business Times, Background Reading, September 27, Johannesburg, Republic of South Africa.

Letters to the Editor. (2015). Why poverty hurts South Africa more than Brazil. Mail and Guardian, October 23 to 29, Johannesburg, Republic of South Africa.

Lings, K. (2015). Rate hike reflects risks to rand and inflation. Business Report, Opinion and Analysis, July 24, Johannesburg, Republic of South Africa.

Lisa, S. (2015a). Caught between the yen and a hard dollar. Mail and Guardian, Business, August 14 to 20 , Johannesburg, Republic of South Africa.

Lisa, S. (2015b). Nene delivers budget under siege. Mail and Guardian, Business, October 23 to 29 , Johannesburg, Republic of South Africa.

Mariam, I. (2015a). Dipping into savings to pay monthly bills. Sunday Times, Business Times, October 25, Johannesburg, Republic of South Africa.

Mariam, I. (2015b). Downgrade risk makes Nene's job even trickier. Sunday Times, Business Times, Johannesburg, Republic of South Africa.

Mariam, I. (2015c). Nene keeps the credit agency wolves from the Treasury door. Background reading, Sunday Times, Business Times, October 25, Johannesburg, Republic of South Africa.

Maynier, D. (2015). Brave thinking must free us from debt and joblessness. Business Report, Opinion and Analysis, October 20.

Mercury Correspondent. (2015). Zuma axes Nene, rand plummets. The Mercury, December 10, Durban, Republic of South Africa.

Mkokeli, S., \& Paton, C. (2015). Nene fired in shock Cabinet reshuffle. Business Day, December 10, Johannesburg, Republic of South Africa.

Mnyandu, E. (2015). Is this the picture we want to show the world? Business Report, October 22, Opinion and Analysis, October 22, Johannesburg, Republic of South Africa.

Mnyandu, E., \& Khuzwayo, W. (2015). Chaos rocks Nene’s budget. Business Report, October 22, Johannesburg, Republic of South Africa.

Mothata, L. (2015). New data show our debt is growing at alarming speed. Business Day, Fiscal Policy Opinion, October 20, Johannesburg, Republic of South Africa.

Nene, N. (2015). Mid Term Policy Statement on the Mini-Budget of South Africa. The South African Treasury, Background Reading, Pretoria, Republic of South Africa.

Nkosi, K. S. (2015). The abyss we are facing now has built up for some time. Business Report, October 23, Johannesburg, Republic of South Africa.

SABC News. (2015). Increase in Repo Rate by 25 Basis Points. November 19, Johannesburg, Republic of South Africa.

SAPA and the SA Media. (2015). Major South African Banks downgraded to BBB-(Minus). Johannesburg, Republic of South Africa.

The Star. (2015). Nene urged to cut fat rather than hike taxes. October 21, Johannesburg, Republic of South Africa.

Thornton, G. (2015). International Business Report. Q3, London, United Kingdom. 
Treasury Bulletin. (2015). Department of Finance. Pretoria, Republic of South Africa.

Vollgraaff, R. (2015). Government policies dent business confidence. Business Report, December 8, Johannesburg, Republic of South Africa.

Wright, T. (2015). Rising Debt in Asia Hurts Growth. The Wall Street Journal, April 22, Background Reading, Middle East Edition, Dow Jones, United States of America.

\section{Copyrights}

Copyright for this article is retained by the author(s), with first publication rights granted to the journal.

This is an open-access article distributed under the terms and conditions of the Creative Commons Attribution license (http://creativecommons.org/licenses/by/3.0/). 